\title{
DETECTING ASSET IMPAIRMENT EARNINGS MANAGEMENT ON IFRS CONTEXT: SOME EVIDENCE FROM GREEK LISTED COMPANIES
}

\author{
${ }^{1}$ Ekaterini C. Laskaridou, ${ }^{2}$ Vazakidis Athanasios and ${ }^{3}$ Athianos Stergios \\ ${ }^{1,2}$ Department of Applied Informatics, University of Macedonia, Thessaloniki, Greece \\ ${ }^{3}$ Department of Financial Accounting, T.E.I of Kentriki Macedonia, Serres, Greece
}

Received 2014-01-14; Revised 2014-01-16; Accepted 2014-04-10

\begin{abstract}
The purpose of this study is two fold: (a) to bring on issues of asset impairment manipulation in the IFRS context (b) to examine, any statistical inference validating impairment discretionary charges and firms' earning experience. The Impairment Accounting Standard (IAS 36), enters new requirements for asset impairment provided to satisfying accrued loss amounts. Earning Management through the use of asset impairments within constrains of taking accounting process results to income manipulation representing (a) an external demand to meet earnings forecasts (b) internal demand for communicating board' level performance. We expect to present a critical view of the earnings discretion and provide an answer on the prevailing content of asset impairment. The sample constituted of 236 firms, listed in the Greek Stock Exchange Market on the basis of impairment observations. We analyze the earnings levels for impairer companies, for 2004-2012 years. Findings suggest (a) firms recording impairment charges possess lower earnings than do their counterparts not recording write downs and (b) the impairment losses are likely reported as timely opportunity to taking "big bath" and increasing future earnings. However we estimate that Greek firms' operating performance is engaged to earning adjustments on (a) taxable environment and (b) new accounting rules liable to income strategies.
\end{abstract}

Keywords: Earnings Management Impairment Accounting, IFRS, IAS

\section{INTRODUCTION}

\subsection{Literature Review}

The earnings management encompasses structuring income numbers transactions in order to achieve (a) preferential earnings forecasts and increase share price and (b) internal managing ability to optimize company's performance. Many studies classified as "income smoothing implying that a write-down is used to neutralize abnormal net income in order to create hidden reserves for later periods. The "big bath" is viewed to be a signal to investors that the balance sheet has been made "clean" of negative features that implies depressing future accounting returns. Zucca and Campbell (1992) analyzed 77 cases of impairment accounting for 1978-
1983 and found that most of them could be classified as a "big bath", being the culmination of a period with low or negative net income. Jordan and Clark (2004) findings also support big bath theory, by analyzing 100 companies prior and after adoption of SFAS 142 for goodwill. However Strong and Meyer (1987) found that, when controlling for industry sector, write-down companies were neither the best nor the worst performers in the years prior to the write-down. Francis et al. (1996) also do not provide evidences for the aspect that writedown companies are either "bathers" or "smoothers". On the contrary, they find that indicators of asset impairment (e.g., book-to-market ratios) are important to explain write-downs. Rees et al. (1996) find that write-downs generally take place in years with low earnings (and therefore accentuate these), but find no statistically Correspondent Author: Ekaterini C. Laskaridou, Department of Applied Informatics, University of Macedonia, Thessaloniki, Greece 
significant support for the hypothesis that management exploit impairment accounting to manipulate earnings. Elliott and Shaw (1988) found that write-down companies earn less than non-write-down firms (adjusted for the write-down), both in absolute and relative terms and that they are systematically larger and more highly leveraged than others.

Hilton and Brien (2009) exploited a clinical study on Inco Ltd's (nickel mining company) financial statement using market prices. They provided a detailed aspect on writedown discretionary decision as findings strongly support that management opportunism remain strong under any new accounting standard and it serves mainly income performance. Financial markets also seem to react to impairment decision according to Liberatore and Mazzi (2010) Study in European listed companies (S and P Europe 350) for 2006-2007 years. Their findings document that market operators do not indifferent to impairment announcements. Impairment decision frequently associated with downward earnings since the managers having a bad profit year would presumably wish to recognize future cost by clearing the decks. Many firms strategically make large write offs in order to start afresh. There are important signaling implications in terms of semi-strong financial market efficiency regarding the information content of asset impairment. Markets interpret an asset impairment announcement as negative signal on firm's prospects mainly for distressed firms (Datta et al., 2005). Analysts' forecasts formulate investment strategies, Lye et al. (2002) examined the writedown decision on Singapore firms where aggregative upward asset revaluation are permitted grading that frequent asset upwards (positively related firm's performance Aboody (1996) implies frequent asset write-downs as earnings smoothing tool.

Asset impairment (Write-down) event as component of earnings management: The growing cogency of asset write-down is reflected in the financial press and by recent academic empirical research. Reuters web site article (27 Tue 2009) by Tom Freke and Quentin Webb, reports "Major European companies may be forced into writedowns totalling hundreds of billions of euros as they recognize the fallout from a 1.8 trillion euro $(\$ 2.7$ trillion) acquisition binge earlier this decade. The writeoff literature focuses on four main areas, (a) the effects of write-offs on returns, (b) the relationship of earnings and write-downs, (c) the impact of IAS 36 on writedowns announcements and d) the relations between the governance of a firm and the motivation to take writedowns as a business related decision. On the basis performance measure hypothesis management exploits earning tools in order to produce the more effective performance measure, timely related to earning goals. So regarding the write-offs, it is expected to reflect either declines in values or changes in management strategies and economic environment or to provide signal to investors for past problems dealt with. On the other hand the opportunistic management hides discretional incentives to developing techniques such as "big bath" to reduce the already depressed earnings and increasing future earnings and their bonuses. Under this setting, impairment asset decision can be hold as purposeful intervention of reporting income.

\section{MATERIALS AND METHODS}

\subsection{Hypothesis Development}

Based on prior empirical results we develop our hypothesis. The Earnings multiples returns are subject to firm economic circumstances with objective fluctuations. Management often manipulates the accounting content of earnings multiples adjusted to stakeholders' perceptions in terms of normalizing asymmetry information (Lang and Lundholm, 1993; Cotter et al., 1998; Wyatt, 2005). Signaling theory supports that firms experienced high performance returns are highly disclosed by reveal private information about future earnings. In contrast the firms with poor performance returns draw the stakeholders' skepticism implying the management intervenes in the reporting process with financial reporting implications.

The performance measure (incentives) hypothesis state that earnings multiples objective to opportunistic management are: (a) The return on asset (ROA-before taxes) (b) the return on equity (ROE-before taxes) and (c) the return on sales (ROS-before taxes). These performance multiples encompass the firm' investment plans, the future performance expectations and the intertemporal economic fluctuations as well (Tucker and Paul, 2005). In practice the management develops discretional policies to impairment making decision accordingly to stakeholders' and financial analysts' performance future targets. In line with prior empirical results (Francis et al., 1996; Riedl, 2004; Beatty and Weber, 2003) the determinants ROA, ROS and ROE reflect the endogenous economic environment and consist the performance explanatory variables. When the firm' overall performance is below the desirable levels the management will be more likely to adopt impairment approach triggering recognition impairment losses in order to reinstate the performance in future (Fields et al., 2001). The Lapointe-Antunes et al. (2008) suggest that firms' performance incentives are linked to both overstate and understate effectively the market value. 
H1: Firms experienced poor performance with negative returns is more likely to recognize impairment losses.

Based on the main earnings management techniques "Big Bath" and "Income Smoothing" we adopt a proxy incorporated the two discretionary accounting procedures. The "INCsmooth" and "BIGbath" reflect the explanatory earnings management variables. Under the circumstances of unexpectedly low earnings levels management has the incentive to engage in earnings management by clearing the deck and boosting the firm' return rates in subsequent years. The reasoning for the development of "Income smoothing" is subject to purposeful intervention in the process of reporting income by dampening the fluctuations of reported numbers around their trend. Via both techniques management might attempt to minimize the risk of possible dept and dividend covenant violations or creating an advantageous financial position conductive to enhancing rates of return:

H2(a): The recognition of impairment losses is more likely when earnings are 'unexpectedly' high (income smoothing).

H2(b): The recognition of impairment losses is more likely when earnings are 'unexpectedly' low (bigbath).

\subsection{Sample Selection}

Our sample consists of all domestic listed companies in ASE which prepared the consolidated financial statement under IFRS during the period 2004-2012. All data retrieved with hand picking method by http://www.ase.gr/content/gr/Companies/ListedCo/Profil es/web page. In our sample, there is not any company with negative book value. Furthermore, a few companies were excluded, as their financial statements were not obtained or, were under supervision for the examining period. The sample consists of all market capitalization database and industry sectors excluding Banks and Insurance companies because of their individual nature of their Asset. The final sample consist of 176 companies and reflect the Greek substance. Through inspecting the annual reports we find a large variation in presentation of impairment account that requires individual judgment which is likely to narrow the credibility of used accounts.

\subsection{Model Development}

The employed methodology base on Van De Poel et al. (2008) model, in which analyzed data by 15 European countries (Greece included) and support that financial reporting is subject to earnings management, grounding the firms' reporting incentives. The asset impairment decision making is highly associated with financial reporting incentives concerning potentially negative stock market reactions. Other factors as macroeconomics figures and corporate government elements are undervalued by the substance of influence the firms' market value. In addition, Siggelkow and Henning (2013) was developed a relative research model and also justified the high statistical substance of financial reporting incentives obscuring other important factors as corporate governance and financial crisis. The Van de Poel et al. (2008) model was employed also by Lemans (2009) in a research were taken account as a sample, German listed companies supporting (a) the impairment decision making is highly associated with "income smoothing" policies and (b) the discretionary accounting practices within IAS 36 impairment valuation methods. In line with prior empirical results we compose the research model on the basis of reporting incentives, firm returns and IAS 36 constituted context. We asses that model of Van de Poel et al. (2008) appropriately incorporate reporting incentives, economic conditions and impairment valuation methods, bringing up the management accounting discretionary policies.

According to the above, the research model can be stated as follows:

$$
\begin{aligned}
& \text { Impairment it }=\alpha_{\mathrm{o}}+\alpha_{1} \text { ChngROA }_{\mathrm{it}}+\alpha_{2} \text { ChngROE }_{\mathrm{it}} \\
& +\alpha_{3} \text { ChngROS }_{\mathrm{it}}+\alpha_{4} \text { INCSmooth }_{\mathrm{itt}}+\alpha_{5} \text { BIGBath }_{\mathrm{it}}+\varepsilon_{\mathrm{it}}
\end{aligned}
$$

Where:

Impairmentit $=\mathrm{A}$ dichotomous variable taking the value 1 when firm impair asset in year $t$ and 0 otherwise

ChngROA $_{i t}=$ The change in firms' Return On Assets (ROA) from year $\mathrm{t}-1$ to $\mathrm{t}$ divided by total asset

ChngROE $_{\text {it }}=$ The change in firms' Return On Equity (ROE) from year $\mathrm{t}-1$ to $\mathrm{t}$ divided by total asset

ChngROS = The change in firms' Return On Sales (ROS) from year $\mathrm{t}-1$ to $\mathrm{t}$ divided by total asset

INCSmooth $_{\text {it }}=$ The variable is determined by focusing on only the positive changes in earnings. This means that when the positive change in earnings before tax

BIGBath $_{\mathrm{it}}=$ The variable is determined based on the negative change in earnings before tax (= operating earnings at time $\mathrm{t}$ less net income plus taxes at time $\mathrm{t}-1$, divided by total assets at time $\mathrm{t}-1$ ) 
The two variable INCSmooth and BIGBath have been used as described by Francis et al. (1996) research where named as 'Poor' and 'Good'.

\section{RESULTS}

Important to notice the Table 1 that emphasizes in sizeable impaired asset categories. Considering the mandate IAS adoption by Greek Companies in the start of 2005 and the sizable impairment increase at $58 \%$ from 2004 (Greek GAAP) to 2005 it is confirmed the important influence and effect of IAS in the reporting financial statements. Furthermore the high level impairment amounts from 2005 to 2006 at $351 \%$ suggest that Greek companies faced the new IAS 36.126 disclosure requirements with large impairment losses. Moreover notable is the proportion of increasing level impairments to decreasing impaired firm number for 2006-2008 years. Finally the period 2009-2010 with higher impairment losses signals the start of economic crisis in Greece with asset price volatility.

Moreover, Table 2 shows the descriptive values for model variables. Regarding the performance incentive variables ROA, ROE and ROS the mean and median values show high variance with high dispersion levels among max and min prices as well. It is also the same for reporting incentive variables. Finally the Skewness and Kurtosis statistics suggest asymmetrical distribution for model variables. Furthermore, in terms of economic significance a decreasing value in mean $(0.61 \%)$ of 'Bigbath' variable by one measure of $0.028218 \%$ standard deviation revalues the impairment amounts by $0.2510 \%$ lessen measure. This stands for overall model variables providing an effect ratio on impairment value. However in the present research we didn't present an accumulative effect on impairment value based on proportional changes in independent variable means caused by their standard deviation measures.

Finally, in Table $\mathbf{3}$ we observe that correlation coefficients are indicative of no implying linear relationship among dependent and independent model variables. That allows coefficients $\alpha_{0}, \alpha_{v}$ to be statistical significant.

The Table 4 presents the coefficient values for model variables. The BIGBath coefficient shows a negative sign with significant correlation at $\mathrm{p}<0.05$ distinctly reveal that firms experienced negative earnings are more likely to taking impairment decision ( $\mathrm{H} 2 \mathrm{~b})$.

Table 1. Descriptive statistics impairment losses by asset classification (IAS 36)/year

\begin{tabular}{|c|c|c|c|c|c|c|}
\hline \multirow[b]{2}{*}{$\begin{array}{l}\text { Year/firm } \\
\text { number }\end{array}$} & \multirow[b]{2}{*}{ Goodwill } & \multicolumn{5}{|c|}{ Asset classification } \\
\hline & & Tangible & Intangible & $\begin{array}{l}\text { Investments subsidiaries, } \\
\text { associates and joint } \\
\text { ventures }\end{array}$ & Other & Total \\
\hline $2004 / 34$ & & $35,559,346$ & & & & $35,559,346$ \\
\hline $2005 / 54$ & $47,769,000$ & $62,517,973$ & $22,304,823$ & $68,278,000$ & $8,417,817$ & $209,287,613$ \\
\hline 2006/49 & 20,823 & $941,319,651$ & $2,430,270$ & & & $943,770,745,56$ \\
\hline $2007 / 27$ & & $790,861,843$ & $94,017,496$ & & & $884,878,960,28$ \\
\hline $2008 / 20$ & $4,902,470$ & $745,263,254$ & $124,408,393,88$ & & & $874,574,118,51$ \\
\hline $2009 / 60$ & 449,000 & $702,222,939$ & $266,195,202,75$ & $37,855,159$ & $2,391,410$ & $1,009,113,710,83$ \\
\hline $2010 / 73$ & $41,325,324$ & $790,447,129$ & $308,800,177$ & $877,969,222$ & 953,390 & $2,019,495,241,61$ \\
\hline 2011/61 & 449,000 & $156,437,183$ & 612,347 & $86,277,702$ & $46,747,355$ & $290,523,567$ \\
\hline $2012 / 74$ & $4,635,633$ & $268,431,153$ & 900,000 & $361,382,040$ & $18,004,599$ & $653,353,425$ \\
\hline Total & $99,551,250$ & $4,493,060,471$ & $819,668,709,63$ & $1,431,762,123$ & $76,514,571$ & $6,920,556,727,79$ \\
\hline$\%$ total & $1.44 \%$ & $64.93 \%$ & $1.84 \%$ & $20.68 \%$ & $1.10 \%$ & $100 \%$ \\
\hline
\end{tabular}

Table 2. Descriptive statistics impairment variables model

\begin{tabular}{lrrrrrr}
\hline \multicolumn{1}{c}{ Mean } & Impairment & \multicolumn{1}{c}{ BIGbath } & \multicolumn{1}{c}{ ChngROA } & \multicolumn{1}{c}{ ChngROS } & \multicolumn{1}{c}{ ChngROE } & INCSmooth $_{\text {i }}$ \\
Median & 0.251082 & -0.006138 & -22.71504 & 0.010923 & 0.072118 & 0.004944 \\
Maximum & 0.000000 & 0.000000 & -17.01000 & 0.062000 & 0.065000 & 0.000000 \\
Minimum & 1.000000 & 0.172000 & 989.43000 & 9.515000 & 1.640000 & 0.715000 \\
Std. Dev. & 0.000000 & -0.391000 & -923.78000 & -13.519000 & -2.745000 & -0.174000 \\
Skewness & 0.433792 & 0.034356 & 166.18670 & 0.856188 & 0.225379 & 0.042700 \\
Kurtosis & 1.148050 & -4.920719 & 0.095962 & -6.050051 & -1.738175 & 6.093896 \\
Jarque-Bera & 2.318019 & 47.581730 & 12.746150 & 109.168100 & 42.376720 & 82.837340 \\
Probability & 0.05231800 & 120373.200000 & 5487.647000 & 659393.800000 & 90240.790000 & 376676.900000 \\
Observations & 1611.000000 & 0.059246 & 0.062584 & 0.058145 & 0.057012 & 0.050792 \\
\hline
\end{tabular}


Table 3. Correlation matrix

\begin{tabular}{|c|c|c|c|c|c|c|}
\hline & Impairment & BIGbath & ROA & ROS & ROE & INCSmooth $_{i}$ \\
\hline IMPAIRMENT & 1.000000 & & & & & \\
\hline BIGBATH & -0.082216 & 1.000000 & & & & \\
\hline $\mathrm{ROA}$ & -0.065269 & 0.008563 & 1.000000 & & & \\
\hline ROS & -0.068653 & 0.181084 & -0.006460 & 1.000000 & & \\
\hline ROE & -0.061475 & 0.258530 & 0.026321 & 0.171296 & 1.000000 & \\
\hline INCSmooth $_{\mathrm{i}}$ & -0.022196 & 0.023784 & 0.023602 & 0.213720 & 0.127755 & 1.000000 \\
\hline
\end{tabular}

Table 4. Regression Results

Impairment it $=\alpha_{\mathrm{o}}+\alpha_{1}$ ChngROA $_{\mathrm{it}}+\alpha_{2}$ ChngROE $_{\mathrm{it}}+\alpha_{3}$ ChngROS $_{\mathrm{it}}+\alpha_{4}$ INCSmooth $_{\mathrm{it}}+\alpha_{5}$ BIGBath $_{\mathrm{it}}+\varepsilon_{\mathrm{it}}$

Panel analysis

\begin{tabular}{|c|c|c|c|c|}
\hline Variable & Coefficient & Std. Error & t-Statistic & Prob. \\
\hline BIGBath $_{\text {it }}$ & -0.990974 & 0.314661 & -3.149343 & 0.0017 \\
\hline INCSmooth $_{\text {it }}$ & -0.063366 & 0.259933 & -0.243777 & 0.8074 \\
\hline ChngROA & -0.229315 & 0.134232 & -1.708352 & 0.0878 \\
\hline ChngROE & -0.06368 & 0.04861 & -1.910028 & 0.0904 \\
\hline Chngros & -0.025164 & 0.013141 & -1.914976 & 0.0557 \\
\hline $\mathrm{C}$ & -1.131406 & 0.152157 & -7.435802 & 0.0000 \\
\hline R-squared & 0.577159 & Mean dependent var & & 0.248603 \\
\hline Adjusted R-squared & 0.573274 & S.D. dependent var & & 0.432354 \\
\hline Akaike info criterion & 1.089637 & F-statistic & & 19.85753 \\
\hline Schwarz criterion & 1.115382 & Prob (F-statistic) & & 0.000000 \\
\hline Hannan-quinn criter. & 1.09925 & & & \\
\hline Durbin-watson stat & 0.161117 & & & \\
\hline
\end{tabular}

*significant level: $\mathrm{p}<0.10$

**significant level: $\mathrm{p}<0.05$

***significant level: $\mathrm{p}<0.01$

Considering the ChngROA and ChngROE coefficients show also negative sign with significant correlation at $\mathrm{p}<0.10$ demonstrating that firms with reducing performance returns might be prone to impairment charges and highly affect the impairment price (H1). Regarding the ChngROS coefficient shows a negative sign with significant correlation at $\mathrm{p}<0.05$ strengthening the performance measure theory and affecting the impairment making decision as well (H1). In addition, the existence of negative correlation of INCSmooth $_{\mathrm{i}}$ coefficient does not support the null hypotheses while the significance of probability relay on $\mathrm{p}<0.10$ which is not play a significant (statistical) role on price specification of the depended variable (Impairment), (H2b).

\section{DISCUSSION}

The hypothesis development, grounded by performance theory on the financial position basis (La Porta et al., 1998; Gassen and Sellhorn, 2006). The accounting alternative practices (reserves' compose) strongly support earnings management policies and equity valuation methods (Kadous et al., 2003; Hunton and Rose, 2006). In present study the subject of interest is the influence of management on the impairment procedures. Our findings support that companies typically take their impairments when earning ratios are exceptional high/low. Furthermore the legislative IFRS procedures do not dominate on management incentives.

\section{CONCLUSION}

Considering the hypothesis robust with significant statistical levels for ChngROS at $\mathrm{p}<0.05$ and ChngROA, ChngROE at $\mathrm{p}<0.10$ reveal that impairment procedures may distorted by performance incentives influencing the reporting financial statements as well. Furthermore the Bigbath at $\mathrm{p}<0.05$ significant level implies that impairment decision get in 'smoothing' path via bigbath techniques. On the other hand the 'Income smooth' technique at $\mathrm{p}<0.10$ significant level doesn't support the neutralization of exceptional earnings. Consequently we assess that sizeable income losses defined the type of management intervenes in the reporting process. 


\section{ACKNOWLEDGEMENT}

The researchers would like to acknowledge the financial support provided by the Research Committee of the Technological Educational Institute (T.E.I.) of Kentriki Makedonia, Greece.

\section{REFERENCES}

Aboody, D., 1996. Market valuation of employee stock options. J. Account. Econom., 22: 357-391. DOI: 10.1016/s0165-4101(96)00439-9

Beatty, A. and J. Webber, 2003. The effects of debt contracting on voluntary accounting method changes. Account. Rev.

Cotter, J., D. Stokes and A. Wyatt, 1998. An analysis of factors influencing asset writedowns. J. Account. Finance, 38: 157-179. DOI: 10.1111/1467-629X.00008

Datta, S., M. Iskandar-Datta and K. Raman, 2005. Managerial stock ownership and the maturity structure of corporate debt. J. Finance, 60: 23332350. DOI: $10.1111 / \mathrm{j} .1540-6261.2005 .00800 . \mathrm{x}$

Elliott, J.A. and W.H. Shaw, 1988. Write-offs as accounting procedures to manage perceptions. J. Account. Res., USA, 26: 91-119.

Fields, T.D., T.Z. Lys and L. Vincent, 2001. Empirical research on accounting choice. J. Account. Econom., 31: 255-307. DOI: 10.1016/S0165-4101(01)00028-3

Francis, J., J. Hanna and L. Vincent, 1996. Causes and effects of discretionary asset write-offs. J. Account. Res., 34: 117-134.

Gassen, J. and T. Sellhorn, 2006. Applying IFRS in germany: Determinants and consequences. Betriebswirtschaftliche Forschung und Praxis, 58: 365-386. DOI: 10.2139/ssrn.906802

Hilton, S.A. and P.O. Brien, 2009. Inco LTD: Market value, fair value and management discretion. J. Account. Res,. 47: 179-211. DOI: 10.1111/j.1475679X.2008.00314.X

Hunton, J.E. and J. Rose, 2006. Can directors' selfinterests influence accounting choices. Account. Organiz. Soc., 33: 783-800. DOI: 10.1016/j.aos.2007.10.001

Jordan, C. and S. Clark, 2004. Big bath earnings management: The case of goodwill impairment under SFAS No. 142. J. Applied Bus. Res., 20: 63-79.

Kadous, K., J.S. Kennedy and M.E. Peecher, 2003. The effect of quality assessment and directional goal commitment on auditors' acceptance of clientpreferred accounting methods. Account. Rev., 78: 759-778. DOI: $10.2308 /$ accr.2003.78.3.759
La Porta, R., F. Lopez-de-Silanes, A. Shleifer and W.R. Vishny, 1998. Law and finance. J. Political Economy, 106: 1113-1155.

Lang, M. and R. Lundholm, 1993. Cross-sectional determinants of analyst ratings of corporate disclosures. J. Account. Res., 31: 246-271. DOI: $10.2307 / 2491273$

Lapointe-Antunes, P., D. Cormier and M. Magnan, 2008. Equity recognition of mandatory accounting changes: The case of transitional goodwill impairment losses. Canadian J. Admin. Sci., 25: $37-$ 54. DOI: $10.1002 /$ cjas.41

Lemans, J.D., 2009. Goodwill impairment as a tool for earnings management. Erasmus MC: University Medical Center Rotterdam.

Liberatore, J. and F. Mazzi, 2010. Goodwill write-off and financial market behaviour: An analysis of possible relationships. Adv. Account., 26: 333-339. DOI: 10.1016/j.adiac.2010.08.001

Lye, A., L. Chye and T.H. Tan, 2002. Asset write-offsmanagerial incentives and macroeconomic factors. Abacus, 38: 134-151. DOI: 10.1111/14676281.00101

Rees, L., S. Gill and R. Gore, 1996. An investigation of asset write-downs and concurrent abnormal accruals. J. Account. Res., 34: 157-169.

Riedl, E.J., 2004. An examination of long-lived asset impairments. Account. Rev., 79: 823-852.

Siggelkow, L. and Z. Henning, 2013. Determinants of the write-off decision under IFRS: Evidence from Germany. Int. Bus. Econom. Res. J., 12: 737-754.

Strong, J. and J. Meyer, 1987. Asset writedowns: Managerial incentives and security returns. J. Finance, 42: 643-661. DOI: 10.1111/j.15406261.1987.tb04574.x

Tucker, J.W. and Z. Paul, 2006. Does Income Smoothing Improve Earnings Informativeness? Account. Rev., 81: 251-270. DI: 10.2308/accr.2006.81.1.251

Van De Poel, K., S. Maijoor and A. Vanstraelen, 2008. Implementation of IFRS within Europe: The case of goodwill. University of Antwerp.

Wyatt, A., 2005. Accounting recognition of intangible assets: Theory and evidence on economic determinants. Account. Rev., 8: 967-1003. DOI: 10.2308/accr.2005.80.3.967

Zucca, L.J. and D.R. Campbell, 1992. A closer look at discretionary writedowns of impaired assets. Account. Horizons, 6: 30-41. 